\title{
HOW TO MISREAD A DICTIONARY
}

\author{
George A. Miller \\ Department of Poychology \\ Princeton University \\ Princeton, NJ 08641
}

A dictionary is an extremely valuable reference book, but its familiarity tends to blind adults to the high level of intelligence required to read it. This aspect becomes apparent, however, when school children are observed learning dictionary skills.

Children do not respect syntactic category and often wander into the wrong lexical entry, apparently in search of something they can understand. They also find it difficult to match the sense of a polysemous word to the context of a particular passage. And they repeatedly assume that some familiar word in a definition can be substituted for the unfamiliar word it defines.

The lexical information that children need can be provided better by a computer than by a book, but that remedy will not be realized if automated dictionaries are merely machinereadable versions of the standard printed dictionaries. Some suggestions for computer-based lexical reference systems will be offered. 